\title{
Influence of Soil Physical Properties on Grapevine Yield and Maturity Components in an Ultic Palexeralf Soils, Central-Southern, Chile
}

\author{
Celerino Quezada1 ${ }^{*}$, Maria A. Soriano², José Díaz¹, Ricardo Merino¹, Alejandro Chandía1, \\ Jorge Campos ${ }^{1}$, Marco Sandoval ${ }^{1}$ \\ ${ }^{1}$ Faculty of Agronomy, University of Concepcion, Chillan, Chile \\ ${ }^{2}$ Department of Agronomy, University of Cordoba, Cordoba, Spain \\ Email: cequezad@udec.cl
}

Received 12 February 2014; revised 12 March 2014; accepted 19 March 2014

Copyright (C) 2014 by authors and Scientific Research Publishing Inc.

This work is licensed under the Creative Commons Attribution International License (CC BY).

http://creativecommons.org/licenses/by/4.0/

(c) (i) Open Access

\begin{abstract}
The effects of soil physical properties on yield components, grape quality and grapevine yield cv. Cabernet Sauvignon in Ultic Palexeralf soils located in Central Southern Chile were assessed. The experimental design was completely randomized with three treatments of soil texture: clayey, sandy clay and clayey loam. The higher yield was obtained in the sandy clay and clayey loam soils. The increase of bulk density, penetration resistance and clay content decreased the number of clusters per vine, number of berries per cluster and grapevine yield. Soil texture had not effects on the yield of shoots, berry diameter and total acidity. However, soluble solids were higher in the clayey soil. Shoot orientation only had positive effects on the cluster weight, number of berries per cluster, and grapevine yield, being higher in the upward shoots. This research remarked the importance of soil physical properties on the selection of sites with viticultural aptitude.
\end{abstract}

\section{Keywords}

Penetration Resistance, Bulk Density, Vineyard, Upward Shoots

\section{Introduction}

Both productivity and quality of grapevine are the results of climate-soil-plant interactions, and together with vi-

${ }^{*}$ Corresponding author.

How to cite this paper: Quezada, C., et al. (2014) Influence of Soil Physical Properties on Grapevine Yield and Maturity Components in an Ultic Palexeralf Soils, Central-Southern, Chile. Open Journal of Soil Science, 4, 127-135.

http://dx.doi.org/10.4236/ojss.2014.44016 
ticultural and enological technology, the concept of terroir has been determined [1] [2]. According to van Leeuween [3] the effects of climate, soil, and cultivar were found to be highly significant with regard to vine behavior and berry composition, such as the concentration of anthocyanins. However, the impacts of climate and soil were higher than those of the cultivar. Moreover, Ubalde et al. [4] remarked the high correlation between the edapho-climatic factors with yield and quality of grapes $\left(\mathrm{R}^{2}>0.75\right)$.

Soil physical properties essentially regulate the potential volume of soil that can be explored by roots, plant roots growth and distribution, soil water availability, root respiration and exchange of soil oxygen [5], with direct effects on irrigation and vineyard management and berry quality [4] [6]. Moreover, Nagarajah [7] determined that rooting depth was higher in coarse soil; roots were well spread throughout the soil profile, as they are concentrated in the top 40 to $60 \mathrm{~cm}$ in both moderately coarse and fine soil. Soil properties such as the presence of soil profiles impermeable to root penetration, stoniness and presence of gravel lenses have a greater influence on depth distributions than that of genotype, even in deep fertile soils [6] [8].

With respect to soil type, soil forming processes are primarily responsible for differences in soil depth, clay content and available water capacity. These have a direct influence on vineyard management and grape quality [4] [9]. Nevertheless, the principal effect of soil type is on grapevine yield. In this regard, sandy soils showed significant increases of berry weight, yield and vine berries, as compared with clayey or silty soils [3] [10].

Soil texture has impact on weight berry, must and wine composition, but not on vine vigor, although they play an important role in wine sensory attributes [2]. According to Trought et al. [11] fruit soluble solids and $\mathrm{pH}$ were higher and total acidity lower when vines grew on shallow soils. On the other hand, soil type had no significant effect on fruit yield. Nevertheless, Martinez-Casasnovas et al. [12] indicated that the soil variables most correlated with yield are the texture of the top layer and the volumetric soil moisture. Moreover, White [13] considered soil depth, drainage and soil texture as the principal factors in viticulture site selection for vineyard due to their effects upon rooting depths and water availability.

In granitic soils, the soil compaction affects the grapevine yield especially in the inter-row, due to intensive use of farm machinery in different farm operations [14], which decreased the potential yield by the increase of the mechanical resistance to roots penetration, affecting the distribution and functional capacity of the root system to extract water and nutrients [4] [5].

The knowledge on soil-vine interaction is crucial to obtain the yield potential of a cultivar as well as on both production and quality grapevine. Therefore, it is necessary that soil survey and geographic information systems provide more detailed information about the complex interactions among soil texture, nutrients, vine vigour, canopy microclimate and variations in soil geochemistry [2] [15]. The objective of this research was to evaluate the effects of soil physical properties on the yield components, yield and maturity components of Vitis vinífera L. cv. Cabernet Sauvignon in an Ultic Palexeralf soils (Cauquenes Series).

\section{Materials and Methods}

\subsection{Site Description}

A field experiment was carried out at Santa Patricia farm, Quinchamalí zone, Ñuble province, Bio-Bio Region ( $36^{\circ} 36^{\prime} \mathrm{LS}, 71^{\circ} 55^{\prime} \mathrm{LW}, 92$ m.a.s.l.), Chile, during 2008-2009 growing season. This area has a Mediterranean climate and it is located in the central south zone of Chile. The average annual rainfall is $1100 \mathrm{~mm}$ with a $70 \%$ falling in May, June, July and August. Annual reference evapotranspiration is reported as $1100 \mathrm{~mm}$, with a dry period of 4 to 5 months and with 5 - 6 frost-free months. Average annual mean temperature is $13.5^{\circ} \mathrm{C}$ with an average temperature of $3.7^{\circ} \mathrm{C}$ in the coldest month (June) and $28^{\circ} \mathrm{C}$ in the warmest month (January). Annual mean relative humidity is $70 \%$ [16].

The soil is classified as fine, kaolinitic, thermic Ultic Palexeralf (Cauquenes Series), derived from granitic materials, clay loam texture, subangular blocky structure, reddish brown (5YR4/4), slope 11.5\%, moderate permeability, moderate drainage and rapid run off [17].

\subsection{Vineyard Management}

The vineyard covers an area of 60 ha (cv. Cabernet Sauvignon, Merlot and Syrah) planted at $3 \mathrm{~m}$ between rows and $0.8 \mathrm{~m}$ between vines, trained by Scott Henry modified system. This consists in plants with upward shoots alternated with plants downward shoots. These were trained on wire to 90 and $115 \mathrm{~cm}$ above soil. Plants were 
pruned to two buds cordon. The applied fertilization was $86 \mathrm{~kg} \mathrm{~N} \mathrm{ha}^{-1}, 21 \mathrm{~kg} \mathrm{P}_{2} \mathrm{O}_{5} \mathrm{ha}^{-1}, 40 \mathrm{~kg} \mathrm{~K}_{2} \mathrm{O} \mathrm{ha}^{-1}, 19 \mathrm{~kg}$ $\mathrm{CaO} \mathrm{ha}^{-1}, 10 \mathrm{~kg} \mathrm{MgO} \mathrm{ha}{ }^{-1}$ and $1 \mathrm{~kg} \mathrm{~B} \mathrm{ha}^{-1}$. Vines were irrigated by surface drip irrigation, one emitter per vine $\left(4 \mathrm{~L} \cdot \mathrm{h}^{-1}\right)$ at a pressure of $100 \mathrm{kPa}$. Rows had approximately $100 \mathrm{~m}$. long containing 125 vines. The timing varied from 1 to $4 \mathrm{hr}$ and the irrigation frequency of 1 to 2 days. The applied water volume during the growing season was $1261 \mathrm{~m}^{3} \cdot \mathrm{ha}^{-1}$ in clayey, $1987 \mathrm{~m}^{3} \cdot \mathrm{ha}^{-1}$ in sandy clay and $1640 \mathrm{~m}^{3} \cdot \mathrm{ha}^{-1}$ in clayey loam soil.

\subsection{Experimental Design}

The field experiment was carried out in a completely randomized design with factorial arrange of $3 \times 2$, corresponding to soil texture and shoot orientation, respectively. The soils treatments were as follows: $\mathrm{T}_{1}$ : Clayey soil with three replicates of ten homogeneous plants divided in upward and downward shoots, located in the upper zone with concave slope at $81 \mathrm{~m}$ elevation; $\mathrm{T}_{2}$ : Sandy clay soil, with three replicates of ten homogeneous plants divided in upward and downwards shoots, located in the lower zone with convex slope at $74 \mathrm{~m}$ elevation; $\mathrm{T}_{3}$ : Clayey loam soil, with three replicates of ten homogeneous plants divided in upward and downwards shoots, located in the medium zone with concave slope at $77 \mathrm{~m}$ elevation. Each treatment consisted of three replicates of 10 homogeneous plants divided in upward and downward shoots.

\subsection{Soil Physical Properties}

Soil physical properties were determined at 0 - 15, 15 - 30, 30 - 50, 50 - 70 and 70 - 100 cm-depth. Particle size analysis was determined by the hydrometer method and textural class by USDA system. Soil bulk density was determined by the cylinder method. Penetration resistance was determined by 15 measures in rows and 15 measures inter rows by means of a penetrometer (Humboldt, H-4137, Humboldt de México, Ciudad de México, México). Soil water availability/(WA) was determined by the difference between field capacity (FC) and permanent wilting point (PWP) expressed as basis dry weigh (BDW). Field capacity (33 kPa) and permanent wilting point (1500 kPa) were determined by pressure the plate method [18].

\subsection{Yield Components}

The yield components assessed were: number of cluster per vine, cluster weight, number of berries per cluster and berries weight, measured in three replicates of ten alternate plants (five upward shoots and five downward shoots) in each treatment, totalizing 30 plants per experimental unit. From each plant the number of clusters per plant was counted. Two clusters were chosen, basal and distal from the central shoot of each cord (four clusters per plant), in upward and downward plants in each replicate of each treatment, totalizing 120 clusters per treatment. Then, the average weight of the clusters and number of berries per cluster was obtained, excluding those dehydrated and rot. 100 berries were randomly chosen per cluster in order to obtain the average weight of berries.

\subsection{Maturity Components}

The equatorial diameter of 100 berries randomly selected was measured from each cluster by means of a 15 pieces grape caliber of 15 to $28 \mathrm{~mm}$ (Field Instruments, Santiago, Chile). The content of soluble solids ( ${ }^{\circ}$ Brix) was determined in the juice of the berries from all selected clusters, separated by upward and downward plants, by means of a thermo-compensated refractometer (ATC-1E, Atago, Milan, Italy). From each replicate 4 readings were carried out; two for cluster musts from the upper canopy and 2 clusters from the lower canopy. Then, the orientation was averaged in each replicate. In addition, the must was used to obtain total acidity per titration with $\mathrm{KOH} 0.1 \mathrm{M}$, expressed in $\mathrm{g} \cdot \mathrm{L}^{-1} \mathrm{H}_{2} \mathrm{SO}_{4}$. Two titrations per replicate were carried out for musts from the upper canopy and two for the lower canopy. These were then averaged in each replicate of the three treatments.

\subsection{Statistical Analysis}

The variables measured were statistically evaluated by means of analysis of variance (ANOVA). When differences were statistically significant, a least significant difference (LSD) comparison was used to separate means with a 95\% confidence level $(\mathrm{P}<0.05)$. Normality was contrasted with the Shapiro-Wilk test $(\mathrm{P}<0.05)$ and the data were normalized by using square root [19]. 


\section{Results and Discussion}

\subsection{Soil Physical Properties}

Table 1 shows the size-particles distribution, bulk density and water availability for the three soil types. Soil texture showed significant differences $(P \leq 0.05)$ among treatments, with highest clay content in $T_{1}$, silt in $T_{3}$ and sand content in $T_{2}$. These differences are associated with the topographic position, that erosion caused remove and translocation of soils and organic matter from upper soil layers and accumulation in the lower areas. This produced disturbance in the native soil composition and increases the soil variability, affecting vigor and yield grapevine. Therefore, soil forming processes must be taken into account in viticultural zoning [4].

The bulk density (Table 1 ) showed higher values in $T_{1}(P \leq 0.05)$ in comparison with $T_{2}$ and $T_{3}$, specially between 60 and $90 \mathrm{~cm}$-depth obtaining values ranged from 1.50 to $1.70 \mathrm{Mg} \cdot \mathrm{m}^{-3}$ (Figure 1) that affected the vertical roots penetration due to greater clay content [20] and lower macroporosity of $9 \%$ and 5\%, respectively [21]. This reduced the root growth, the water and nutrients uptake, the leaf area and the plant growth [22]. In contrast, $\mathrm{T}_{2}$ showed higher roots density due to higher sand content (46.2\%) improving soil aeration, water infiltration rate, with a higher soil volume for water and nutrients uptake [23].

Water availability presented significant differences $(\mathrm{P} \leq 0.05)$ among soil treatments (Table 1$)$ with lower values in $\mathrm{T}_{1}(11.12 \% \mathrm{BDW}), \mathrm{T}_{2}(6.91 \% \mathrm{BDW})$ and $\mathrm{T}_{3}(8.24 \% \mathrm{BDW})$, due to greater sand content, higher soil bulk density and penetration resistance, that decreased the soil volumetric water content [24].

Penetration resistance showed significant differences $((\mathrm{P} \leq 0.05)$ among soil treatments for inter-row and in-row. The greater values were measured in clayey soil $\left(\mathrm{T}_{1}\right)$ and inter-row due to person traffic and use of farm machinery, causing a higher compaction in fine soils than gravelly soils, affecting the root growth and grapevine performance [4].

The soil bulk density of $\mathrm{T}_{1}\left(1.50\right.$ to $\left.1.70 \mathrm{Mg} \cdot \mathrm{m}^{-3}\right)$ is in accordance with the greater values of penetration resistance in-row (3.57 MPa) and inter-row (5.08 MPa) (Figure 2), that indicated higher soil compaction and decreasing of oxygen diffusion rate in the root system [20].

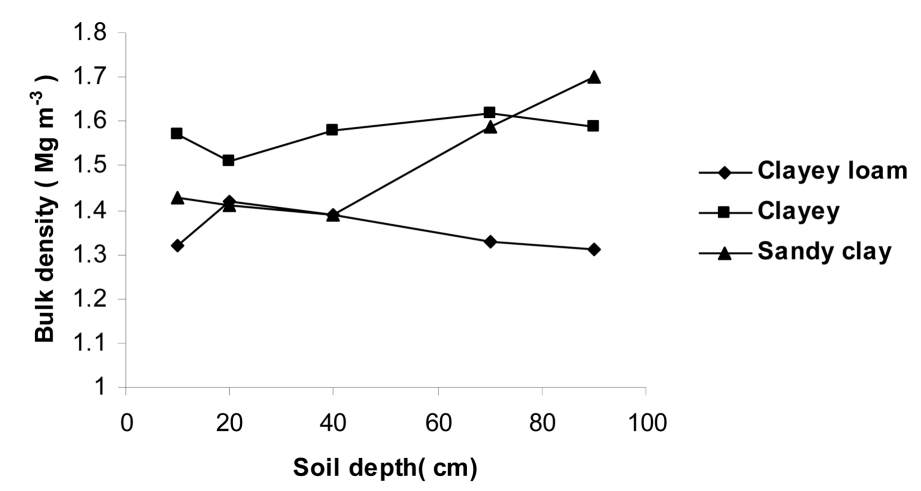

Figure 1. Bulk density $\left(\rho_{\mathrm{b}}\right)$ as a function of depth for three soil texture in an Ultic Palexeralf soils. $\mathrm{T}_{1}$ : Clayey, $\mathrm{T}_{2}$ : Sandy clay, $\mathrm{T}_{3}$ : Clayey loam.

Table 1. Size-particles distribution (\%), bulk density $\left(\rho_{\mathrm{b}}\right)$ and water availability (WA) for three soil textures in an Ultic Palexeralf soils.

\begin{tabular}{cccc}
\hline Physical properties & $\mathrm{T}_{1}$ Clayey & $\mathrm{T}_{2}$ Sandy clay & $\mathrm{T}_{3}$ Clayey loam \\
\hline Clay (\%) & $42.1 \mathrm{a}$ & $31.8 \mathrm{a}$ & $35.3 \mathrm{~b}$ \\
Silt (\%) & $19.6 \mathrm{~b}$ & $19.7 \mathrm{~b}$ & $28.5 \mathrm{a}$ \\
Sand (\%) & $38.3 \mathrm{c}$ & $46.2 \mathrm{c}$ & $36.2 \mathrm{~b}$ \\
$\rho_{\mathrm{b}}\left(\mathrm{Mg} \cdot \mathrm{m}^{-3}\right)$ & $1.59 \mathrm{a}$ & $1.50 \mathrm{a}$ & $1.35 \mathrm{~b}$ \\
WA (\%) & $11.12 \mathrm{a}$ & $6.91 \mathrm{~b}$ & $8.24 \mathrm{~b}$ \\
FC & $29.26 \mathrm{a}$ & $21.04 \mathrm{~b}$ & $20.43 \mathrm{~b}$ \\
PWP & $18.14 \mathrm{a}$ & $14.13 \mathrm{~b}$ & $12.19 \mathrm{~b}$ \\
\hline
\end{tabular}

Different letters in rows indicate significant differences $(\mathrm{P} \leq 0.05)$ according to LSD test; LSD: least significant difference. FC: Field Capacity; PWP: Permanent Wilting Point. WA = FC - PWP. 


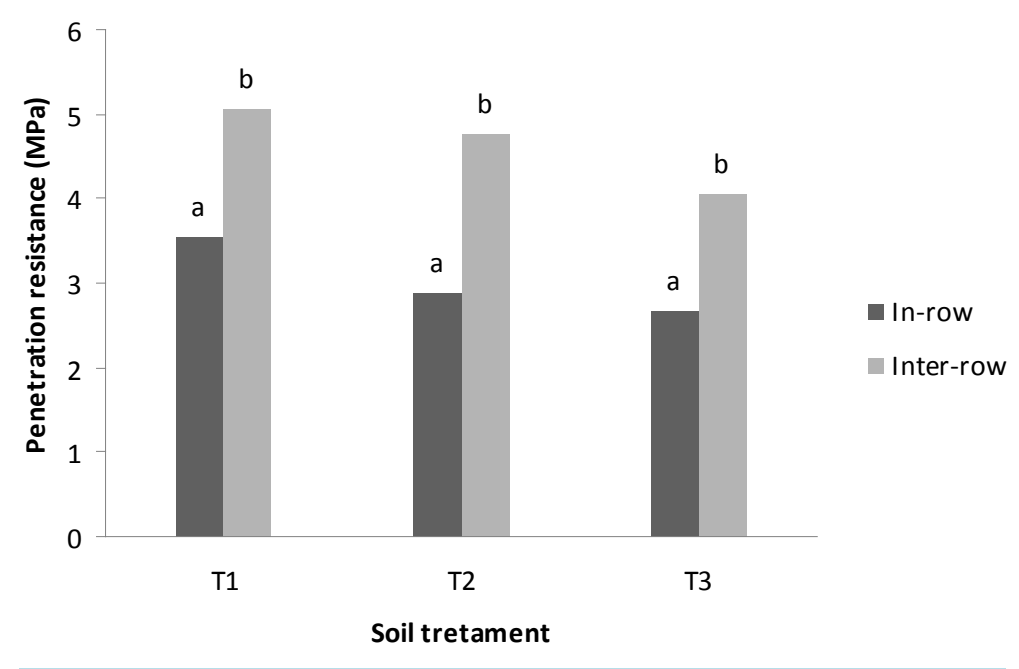

Figure 2. Penetration resistance (MPa) in row and inter-row of cv. Cabernet Sauvignon vineyard drip irrigated for three soil textures in an Ultic Palexeralf soils. Different letters in bars indicate significant differences $(P \leq 0.05)$ according to LSD test; LSD: least significant difference. $\mathrm{T}_{1}$ : Clayey; $\mathrm{T}_{2}$ : Sandy clay; $\mathrm{T}_{3}$ : Clayey loam.

The root growth was influenced by soil compaction due to the high penetration resistance, greater of $3 \mathrm{MPa}$, declining the level production. In this condition, it is not possible to obtain soil macroporosity between $10 \%-15 \%$ regarded as the minimum air porosity to allow gaseous exchange in the rizhosphere [13] [22]. However, the values of penetration resistance can be overestimated in order that soil penetrometer works in lineal form and not tortuous as root growth [25]. Furthermore, in the soil profile was observed a greater root density toward in row, due to roots growing in compacted soils can traverse impenetrable soils by using biopores and structural cracks [24].

\subsection{Yield Components}

Table 2 shows results of yield components of cv. Cabernet Sauvignon in three soil textures. The number of clusters per plant of both shoot orientation did not present significant differences among soil treatments $(\mathrm{P}>$ 0.05), and determined no interaction between shoot orientation and soil texture (Table 2). However, $T_{1}$ obtained the lower number of clusters per plant $(P \leq 0.05)$ as compared with $T_{2}$ y $T_{3}$, due to poor soil physic quality decreasing the root growth and water and nutrients uptake [8].

Shoot orientation did not impact the number of clusters per plant $(\mathrm{P}>0.05)$ among soil treatments (Table 2). However, the increase of clay content and bulk density decreased the number of clusters per plant in $T_{1}$. This can be explained due to the decreasing of the carbohydrate storage level in roots and buds because the starch accumulation in buds showed a positive correlation with the buds fertility during the flowering induction [8] [22].

Soil texture did not affect the cluster weight among shoot orientation $(\mathrm{P}>0.05)$, and not determined interaction between shoot orientation and soil texture (Table 2). However, also $\mathrm{T}_{1}$ showed the lower cluster weight ( $\mathrm{P}$ $\leq 0.05$ ) as compared with $T_{2}$ and $T_{3}$, due to lower number of berries by the effect of greater penetration resistance that decreases the soil macroporosity and gaseous exchange in roots zone. This can be explained for the decreasing of the carbohydrate level and lower water and nutrients uptake [22] [25]. Respect to training system, the cluster weight on the upward shoot was significantly higher for the all soil treatments in comparison with downward shoot $(\mathrm{P} \leq 0.05)$. These results are in accordance to those obtained by Hidalgo et al. [26] and Henríquez [27], who found that the shoot orientation did not affect the berry size in cv. Cabernet Sauvignon, important factor in the wine quality due to skin to pulp ratio in berries.

Soil texture did not affect the number of berries per cluster among shoot orientation $(P>0.05)$, and not determined interaction between shoot orientation and soil texture (Table 2). Again, $\mathrm{T}_{1}$ obtained the lower berries number per cluster in both shoots $(\mathrm{P} \leq 0.05)$ in comparison with $\mathrm{T}_{2}$ and $\mathrm{T}_{3}$ due to negative effect of the greater 
Table 2. Yield components of cv. Cabernet Sauvignon drip irrigated in upward and downward shoot for three soil textures in an Ultic Palexeralf soils.

\begin{tabular}{ccccccccc}
\hline \multirow{2}{*}{ Treatment } & \multicolumn{2}{c}{ Clusters/vine } & \multicolumn{2}{c}{ Cluster wt (g) } & \multicolumn{2}{c}{ Berries/cluster } & \multicolumn{2}{c}{ Berry w (g) } \\
\cline { 2 - 9 } & Upward & Downward & Upward & Downward & Upward & Downward & Upward & Downward \\
\hline & & & & & & & \\
$\mathrm{T}_{1}$ & $40.93 \mathrm{Aa}$ & $41.70 \mathrm{Aa}$ & $85.99 \mathrm{Aa}$ & $76.80 \mathrm{Ba}$ & $75.92 \mathrm{Aa}$ & $67.22 \mathrm{Ba}$ & $1.14 \mathrm{Aa}$ & $1.07 \mathrm{Aa}$ \\
$\mathrm{T}_{2}$ & $44.87 \mathrm{Ab}$ & $44.30 \mathrm{Ab}$ & $104.11 \mathrm{Ab}$ & $88.59 \mathrm{Bb}$ & $89.57 \mathrm{Ab}$ & $76.57 \mathrm{Bb}$ & $1.11 \mathrm{Aa}$ & $1.11 \mathrm{Aa}$ \\
$\mathrm{T}_{3}$ & $44.93 \mathrm{Ab}$ & $43.53 \mathrm{Aab}$ & $103.53 \mathrm{Ab}$ & $83.52 \mathrm{Bb}$ & $82.68 \mathrm{Bab}$ & $70.35 \mathrm{Bab}$ & $1.15 \mathrm{Aa}$ & $1.10 \mathrm{Aa}$ \\
$\mathrm{S}^{*} \mathrm{O}$ & \multicolumn{2}{c}{$0.65 \mathrm{~ns}$} & \multicolumn{2}{c}{$0.12 \mathrm{~ns}$} & \multicolumn{2}{c}{$0.74 \mathrm{~ns}$} & $0.57 \mathrm{~ns}$ \\
\hline
\end{tabular}

Different capital letters in the columns and different lowercase letters in the rows are significantly different $(\mathrm{P} \leq 0.05)$ according to LSD test; LSD: least significant difference; T: Treatment; $\mathrm{T}_{1}$ : Clayey; $\mathrm{T}_{2}$ : Sandy clay; $\mathrm{T}_{3}$ : Clayey loam; S O$^{*}$ Interaction soil texture $(\mathrm{S}) *$ Shoot orientation $(\mathrm{O})$. ns: not significant.

bulk density, penetration resistance and clay content on the vine growth, phothosyntetic activity and decreases of buds fertility [28] [29].

Respect to shoot orientation, upward shoots showed higher number of berries per cluster $(\mathrm{P} \leq 0.05)$ for all soil treatments. These results were also similar to those obtained by Hidalgo et al. [26]. This can be explained by the fact that in the grapevine, the upward orientation inducting higher vigor and xylem hydraulic conductivity than the downward [29]. However, Kliewer et al. [30] found that the number of berries did not differ between upward and downward shoots.

Soil texture did not impact the berry weight among upward and downward shoots ( $(\mathrm{P}>0.05)$, and not determined interaction between shoot orientation and soil texture (Table 2). These results are in accordance to those obtained by Muñoz et al. [31] and Henríquez [27] who did not find significant differences among berry weight associated to shoot orientation. Nevertheless, Hidalgo et al. [26] obtained greater berry weight in upward shoots due to depress of the downward shoot growth.

\subsection{Grapevine Yield}

Grapevine yield presented no significant differences among soil treatments nor within shoot orientation ( $\mathrm{P}>$ 0.05 ), and the interaction between shoot orientation and soil texture (Figure 2) was not determined. The lowest grapevine yield was found in $\mathrm{T}_{1}$ due to the lower number of clusters and number of berries per cluster, probably because of the effect of penetration resistance and clay content on root growth and development. According to Bordelón et al. [32] shoot orientation is not dependent on the soil texture, but more associated to depress of the downward shoot. Therefore, the highest yield was obtained on the upward shoot due to higher total leaf area and stomatal conductance of leaves [29]. These results were similar to those by Hidalgo et al. [26] and Henríquez [27].

\subsection{Maturity Components}

Soil texture did not impact the berry size between upward and downward shoots $(\mathrm{P}>0.05)$, and the interaction between soil texture and shoot orientation (Table 3) was not determined, probably due to different water applied, being higher to $\mathrm{T}_{2}\left(1987 \mathrm{~m}^{3} \cdot \mathrm{ha}^{-1}\right)$ and smaller $\mathrm{T}_{1}$ and $\mathrm{T}_{3}\left(1261\right.$ and $1640 \mathrm{~m}^{3} \cdot \mathrm{ha}^{-1}$ respectively). That allowed obtaining similar moisture among three soil textures. Regarding to Sellés et al. [33], they determined that soil moisture have a direct influence on the berry diameter, with the increase of soil moisture, decrease the penetration resistance, improving the root growth and the movement of cytokynins into berries.

Shoot orientation presented no significant differences in the berry diameter $(P>0.05)$ (Table 3). These results were similar to those obtained by Hidalgo et al. [26] and Henríquez [27], who found that the shoot orientation not affected the berry size in cv. Cabernet Sauvignon. Berry size is an important factor to achieve quality wines that high skin to pulp ratio concentrate color and flavor components, which are passed on to the wine [34].

Soil texture presented no significant differences in soluble solids among upward and downward shoots ( $\mathrm{P}>$ 0.05) and interaction between shoot orientation and soil texture (Table 3) was not observed. Soil texture had significant effects $(P \leq 0.05)$ on soluble solids and $T_{1}$ showed the higher sugar concentration. These results are in accordance to those obtained by Reynolds et al. [2] who found positive correlation between clay content and soluble solids. This can be explained due to soil compaction of $\mathrm{T}_{1}$ reduce root growth and leaf area, modifying 
Table 3. Maturity components of cv. Cabernet Sauvignon drip irrigated in upward and downward shoot for three soil textures in an Ultic Palexeralf soils.

\begin{tabular}{|c|c|c|c|c|c|c|}
\hline \multirow[t]{3}{*}{ Treatment } & \multirow{2}{*}{\multicolumn{2}{|c|}{$\begin{array}{c}\text { Berry size } \\
(\mathrm{mm})\end{array}$}} & \multirow{2}{*}{\multicolumn{2}{|c|}{$\begin{array}{c}\text { Soluble solids } \\
\left.\text { ( }{ }^{\circ} \text { Brix }\right)\end{array}$}} & \multirow{2}{*}{\multicolumn{2}{|c|}{$\begin{array}{l}\text { Total acidity } \\
\left(\mathrm{g} / \mathrm{l} \mathrm{H}_{2} \mathrm{SO}_{4}\right)\end{array}$}} \\
\hline & & & & & & \\
\hline & Upward & Downward & Upward & Downward & Upward & Downward \\
\hline $\mathrm{T}_{1}$ & $12.87 \mathrm{Aa}$ & $12.81 \mathrm{Aa}$ & $26.73 \mathrm{Aa}$ & $27.37 \mathrm{Aa}$ & $3.90 \mathrm{Aa}$ & $4.04 \mathrm{Aa}$ \\
\hline $\mathrm{T}_{2}$ & $12.84 \mathrm{Aa}$ & $12.78 \mathrm{Aa}$ & $25.83 \mathrm{Ab}$ & $26.20 \mathrm{Ab}$ & $4.05 \mathrm{Aa}$ & $3.90 \mathrm{Aa}$ \\
\hline $\mathrm{T}_{3}$ & $12.79 \mathrm{Aа}$ & 12.84 Аа & 24.80 Ac & 25.03 Ac & $4.04 \mathrm{Aa}$ & $3.90 \mathrm{Aa}$ \\
\hline $\mathrm{S}^{*} \mathrm{O}$ & \multicolumn{2}{|c|}{$0.55 \mathrm{~ns}$} & \multicolumn{2}{|c|}{$0.94 \mathrm{~ns}$} & \multicolumn{2}{|c|}{$0.34 \mathrm{~ns}$} \\
\hline
\end{tabular}

Differents lowercase letters in the columns and different capital letters in the rows are significantly different $(\mathrm{P} \leq 0.05)$ according to LSD test; LSD: least significant difference. $T_{1}$ : Clayey; $T_{2}$ : Sandy clay; $T_{3}$ : Clayey loam; $S * D$ : Interaction soil textures (S) * Shoot orientation (O). ns: not significant.

vineyard microclimate, that influenced the sugar content and wine color density. This effect was closely related with the solar radiation intercepted by leaf surface [28] [31]. Nevertheless, probably in $\mathrm{T}_{1}$, the high transpiration rate due to greater water availability $(11.12 \%)$ permitted a greater soluble solid concentration by increasing of photosynthetic rate and photosyntates translocation [35].

Furthermore, not significant differences $(\mathrm{P}>0.05)$ were observed in soluble solids among upward and downward shoots in the three soil treatments, as shown by other authors [26] [27] [32].

Soil texture did not affect the total acidity of the must among upward and downward shoots ( $\mathrm{P}>0.05)$, and no interaction between shoot orientation and soil texture (Table 3) was observed. Furthermore, total acidity did not present significant differences among three soil textures and shoot orientation $(\mathrm{P}>0.05)$. These results are in accordance to those obtained by others authors [10] [26] [32]. In contrast, Reynolds et al. [35] determined that in sandy soil decreased total acidity of wine and increased soluble solids of must.

\section{Conclusion}

The greater yield was obtained in textural class sandy clay and clayey loam. The increase of bulk density, penetration resistance and clay content decreased the number of clusters per vine, cluster weight, number of berries per cluster and grapevine yield. Soil texture did not affect the grapevine yield between upward and downward shoots, berry size and total acidity, but the soluble solids concentration was higher in clayey texture soil. Shoot orientation had positive effects on clusters weight, number of berries per cluster and grapevine yield, being greater in upward shoot. This research remarked the importance of soil physical properties on the site selection with viticultural aptitude.

\section{References}

[1] Deloire, A., Vaudour, E., Carey, V., Bonardot, V. and van Leeuwen, C. (2005) Grapevine Responses to Terroir: A Global Approach. Journal International des Sciences de la Vigne et du Vin, 39, 149-162.

[2] Reynolds, A.G., Senchuk, I.V., van der Rees, C. and de Savigny, Ch. (2007) Use of GPS and GIS for Elucidation of the Basis for Terroir: Spatial Variation in an Ontario Riesling Vineyard. American Journal Enology Viticulture, 58, $145-162$.

[3] van Leeuwen, C., Friant, P., Choné, X., Tregoat, O., Koundouras, S. and Dubourdieu, D. (2004) Influence of Climate, Soil and Cultivar on Terroir. American Journal Enology Viticulture, 55, 207-217.

[4] Ubalde, J.M., Sort, X., Poch, R.M. and Porta, M. (2007) Influence of Edapho-Climatic Factors on Grape Quality in Conca de Barbera Vineyards (Catalonia, Spain). Journal International des Sciences de la Vigne et du Vin, 41, 33-41.

[5] Lanyon, D.M., Cass, A. and Hansen, D. (2004) The Effect of Soil Properties on Wine Performance. CSIRO, Land and Water Technical Report No. 34/4, 54 p.

[6] Smart, D.R., Schwass, E., Lakso, A. and Morano, L. (2006) Grapevine Rooting Patterns: A Comprehensive Analysis and a Review. American Journal of Enology Viticulture, 57, 89-104.

[7] Nagarajah, S. (1987) Effects of Soil Texture on the Rooting Patterns of Thompson Seedless Vine on Own Roots and on Ramsey Rootstock in Irrigated Vineyards. American Journal of Enology Vitiulture, 38, 54-59. 
[8] Morlat, R. and Jacquet, A. (1993) The Soil Effects on Grapevine Root System in Several Vineyards of the Loire Valley (France). Vitis, 32, 35-42.

[9] Montero, F.J. and Brasa, A. (2005) Land and Water Use Management in Vine Growing by Using Geographic Information Systems in Castilla-La Mancha, Spain. Agricultural Water Management, 77, 82-95. http://dx.doi.org/10.1016/j.agwat.2004.09.027

[10] Apcarian, A., Echeñique, M., Aruani, M. and Reeb, P. (2006) Efecto de capas endurecidas de suelos sobre el potencial productivo de viñedos, Alto Valle Río Negro, Patagonia, Argentina. Agricultura Técnica (Chile), 66, 70-79.

[11] Trought, M.C.T., Dixon, R., Mills, T., Greven, M., Agnew, R., Mauk, J.L. and Praat, J.-P. (2008) The Impact of Differences in Soil Texture within a Vineyard on Vine Vigour, Vine Earliness and Juice Composition. Journal International des Sciences de la Vigne et du Vin, 42, 67-72.

[12] Martínez-Casasnovas, J.A., Ramos, M.C. and Vallés, D. (2009) Análisis de la relación entre las propiedades del suelo, el indice de vigor del cultivo y el rendimiento en unviñedo de la D.O. Costers del Segre (Lleida). Teledetección: Agua y desarrollo sostenible, XIII Congreso de la Asociación Española de Teledetección, Catayalud, 37-40.

[13] White, R.E. (2002) Soils for Fine Wines. Oxford University Press, New York.

[14] Hamza, M.A., Al-Adawi, S.S. and Al-Hinai, A. (2011) Effect of Combined Soil Water and External Load on Soil Compaction. Soil Research, 49, 135-142. http://dx.doi.org/10.1071/SR09144

[15] Zou, J.-F., Peng, Z., Du, H., Duan, C., Reeves, M.J. and Pan, Q. (2012) Elemental Patterns of Wines, Grapes, and Vineyard Soils from Chinese-Wine Production Regions and Their Association. American Journal Enology Viticulture, 63, 232-240. http://dx.doi.org/10.5344/ajev.2012.11087

[16] Pozo, L., Alejandro, D., Canto, S. and Pedro, D. (1999) Areas agroclimáticas y sistemas productivos en la VII y VIII regiones. Serie Quilamapu No. 113, INIA Quilamapu, Chillán.

[17] Stolpe, N.B., Zagal, E., Sandoval, M. and Quezada, C. (2008) Southern Field-Guide between $35^{\circ} \mathrm{S}$ and $37^{\circ} \mathrm{S}$. In: Casanova, M. and Luzio, W., Eds., The International Conference \& Field Workshops on Soil Classification: Soil: A Work of Art of Nature, University of Chile, Santiago, 9-18 November 2008, 57-65.

[18] Sandoval, M., Döerner, J., Seguel, O., Cuevas, J. and Rivera, D. (2012) Métodos de análisis físico de suelos. Publicaciones del Departamento de Suelos y Recursos Naturales, Universidad de Concepción, Facultad de Agronomía, Chillán.

[19] Balzarini, M., González, L., Tablada, E., Casanoves, F., Di Rienzo, J. and Robledo, C. (2010) Infostat: Software Estadístico: Manual del usuario. Versión 2004, Brujas Argentinas, Córdoba.

[20] Unger, P.W. and Kaspar, T.C. (1994) Soil Compaction and Root Growth: A Review. Agronomy Journal, 86, $759-766$. http://dx.doi.org/10.2134/agronj1994.00021962008600050004x

[21] Yilmaz, K., Hall, N. and Coscan, P.K. (2003) An Evaluation of Soil Compaction on the Narli Plain Irrigation Area, Kahramanmaras Turkey. Soil Science, 168, 516-528. http://dx.doi.org/10.1097/01.ss.0000080336.10341.f8

[22] Echeñique, M., Apcarian, A., Reeb, P. and Aruani, M.C. (2007) Equilibrio vegetativo-productivo en cultivares de vid sobre suelos con capas endurecidas, Alto Valle de Río Negro, región vitivinícola Sur de Argentina. Agricultura Técnica (Chile), 67, 262-270.

[23] Giulivio, C. and Pitacco, A. (1996) Studying the Root System of Grapevine. Acta Horticulturae, 427, 63-66.

[24] Stirzaker, R.J., Passioura, J.B. and Wilms, Y. (1996) Soil Structure and Plant Growth: Impact of Bulk Density and Biopores. Plant and Soil, 185, 151-162. http://dx.doi.org/10.1007/BF02257571

[25] Bengough, A.G. and Mullins, C.E. (1990) Mechanical Impedance to Root Growth: A Review of Experimental Techniques and Root Growth Responses. Journal of Soil Science, 41, 341-358. http://dx.doi.org/10.1111/j.1365-2389.1990.tb00070.x

[26] Hidalgo, M. (2006) Evaluación de parámetros vegetativos y productivos en plantas orientadas ascendente y descendente en tres cultivares de vid (Vitis vinifera L.). Memoria de título, Ing. Agrón. Universidad de Concepción, Chillán.

[27] Henríquez, R. (2011) Efecto de la orientación de brotes, en el sistema de conducción Scott-Henry, sobre la producción de uva y composición de bayas en tres cultivares de Vitis vinifera L. Memoria de título, Ing. Agrón. Universidad de Concepción, Chillán.

[28] Ruiz, R. (2000) Dinámica nutricional en cinco parrones de diferente productividad del valle central regado de Chile. Agricultura Técnica (Chile), 60, 379-398.

[29] Lovisolo, C. and Schubert, A. (2000) Downward Shoot Positioning Affects Water Transport in Field-Grown Grapevines. Vitis, 39, 49-53.

[30] Kliewer, W.M., Bowen, P. and Benz, M. (1989) Influence of Shoot Orientation on Growth and Yield Development in Cabernet Sauvignon. American Journal of Enology and Viticulture, 40, 259-264. 
[31] Muñoz, R., Pérez, J., Pszczolkowski, P. and Bordeu, E. (2002) Influencia del nivel de carga y microclima sobre la composición y calidad de bayas, mosto y vino de Cabernet-Sauvignon. Ciencia e Investigación Agraria, 29, 115-125.

[32] Bordelón, B.P., Skinkis, P.A. and Howard, P.H. (2008) Impact of Training System on Vine Performance and Fruit Composition of Traminette. American Journal of Enology and Viticulture, 9, 39-46.

[33] Sellés, G., Ferreyra, R., Contreras, G., Ahumada, R., Valenzuela, J. and Bravo, R. (2003) Manejo de riego por goteo en uva de mesa cv. Thompson Seedless cultivada en suelos de textura fina. Agricultura Técnica (Chile), 63, 180-192.

[34] Acevedo-Opazo, C., Ortega-Farías, S. and Fuentes, S. (2010) Effects of Grapevine (Vitis vinifera L.) Water Status on Water Consumption, Vegetative Growth and Grape Quality: An Irrigation Scheduling Application to Achieve Regulated Deficit Irrigation. Agricultural Water Management, 97, 956-964. http://dx.doi.org/10.1016/j.agwat.2010.01.025

[35] Reynolds, A.G., Lowrey, W.D., Tomek, L., Hakimi, J. and De Savigny, C. (2007) Influence of Irrigation on Vine Performance, Fruit Composition, and Wine Quality of Chardonnay in a Cool, Humid Climate. American Journal of Enology and Viticulture, 58, 217-233. 